\section{Herbage Production Following Brush Control with Herbicides in Texas ${ }^{1}$}

\section{R. W. BOVEY, R. E. MEYER, AND H. L. MORTON2}

Agronomist and Plant Physiologists, Plant Science Research Division, Agricultural Research Service, U. S. Department of Agriculture,

Department of Range Science, Texas A College Station.

\section{Highlight}

The herbicides, 4-amino-3,5,6-trichloropicolinic acid (picloram), 5-bromo-3sec-butyl-6-methyluracil (bromacil), (2,4,5-trichlorophenoxy)acetic acid (2,4,5-T), 3,6-dichloro-o-anisic acid (dicamba) applied alone and in certain combinations caused significant increases in grass production for several months to several years at three locations in Texas, depending upon the degree of brush control obtained. Native grasses usually tolerated picloram, 2-chloro-4-(ethylamino)-6(isopropylamino)-s-triazine (atrazine), 2-chloro-4,6-bis(ethylamino)-s-triazine (simazine) and (2,4-dichlorophenoxy)acetic acid (2,4-D) as granules and sprays at rates up to $2 \mathrm{lb}$./acre without reduction in yield on pasturelands at three locations in Texas.

The influence of herbicides on forage production is of major concern on pasture and rangelands, especially after applications of high rates for brush control. Barrons (1969) reviewed the ecological benefits of herbicide usage on range and

\footnotetext{
${ }^{1}$ Received April 4, 1971. Cooperative investigation of the Plant Science Research Division, Agricultural Research Service, U. S. Department of Agriculture and Texas A\&M University, College Station, Texas.

${ }^{2}$ H. L. Morton now at 2000 East Allen Road, Tucson, Arizona.
}

pasturelands and indicated that many areas in the world are covered with unpalatable or poisonous plants that could be controlled to create improved grasslands. Therefore, increasing herbage production while controlling brush and many unpalatable or poisonous plants would increase the value of the treated area. Research is needed to show these herbage increases following herbicide sprays. Klingman and McCarty (1958) on pastures at Lincoln, Nebraska, es-
The comprehensive studies of tablished that weed control increased the consumption of vegetation by livestock $252 \%$ of the check on grazed plots and up to $318 \%$ when grazing was deferred to June 15 and rotationally grazed thereafter. Forage consumption was increased on an average of $20 \%$ by mowing and $47 \%$ by spraying with (2,4-dichlorophenoxy) acetic acid (2,4-D).

Experiments in the Missouri Ozarks by Ehrenreich and Buttery (1960) indicated herbage production was increased 40 to 60 times on plots where hardwood tree competition was reduced by herbicides or a combination of girdling overstory trees and spring burning. Reseeding following control of hardwoods with tall fescue (Festuca arundinacea Schreb.) was recommended for improving herbage quality. Bentley (1967) reported that conversion of chaparral to grass in California was least expensive with 2,4-D and 2,4,5-T, although some species were resistant and required several applications. However, the most difficult phase of the conversion process was establishment of perennial grasses.

In Texas, although reseeding may be desirable in some areas, desirable native species do produce an excellent grass cover after brush 
control with herbicides. In northwest Texas, Fisher et al. (1959) showed over a 10-year period, annual acre-gains of 18 percent with yearling steers on pastures treated with 2,4,5-T, compared to pastures infested with honey mesquite (Prosopis juliflora (Swartz) DC. var. glandulosa (Torr.) Cockerell). Pastures were moderately stocked at 6.5 acres/head for 156 days (May 1 to October 3). This increase was valued at $\$ 1.00 /$ acre/year at that time.

Robison and Fisher (1968) showed increases of 5 times more forage per acre on sprayed than on unsprayed areas infested with sand shinnery oak (Quercus havardii Rydb.). Arnold and Santelmann (1966) studied the effect of picloram on native grasses in the field and greenhouse in Oklahoma. Picloram applied at $3 / 4,1 \frac{1}{2}$ and $3 \mathrm{lb}$./acre prevented secdling growth of blue grama (Bouteloua gracilis (Willd. ex H.B.K.) Lag. ex Griffiths), sideoats grama, big bluestem (Andropogan gerardi Vitman) and switchgrass (Panicum virgatum L.). When applied at the two to four-leaf stage at $1 \frac{1}{2} \mathrm{lb}$./acre, picloram significantly reduced density of all species. However, when picloram was applied to established native range at 1, 2 and $4 \mathrm{lb}$./acre, production of desirable forage grasses was not reduced, but forb production was reduced.

Studies in Central Texas by Meyer et al. (1969) showed that fall and spring applications of picloram increased the production of perennial native grasses and reduced perennial and annual forb production by the next summer. However, total production of vegetation was similar to the untreated areas, regardless of treatment.

Hoffman (1966) increased the grazing potential for cattle from 67 animal units to 178 on 1000 acres after spraying Macartney rose infested pastures with 2,4-D in southeast Texas. The unsprayed area produced an average of 2,482 pounds of forage per acre; whereas the sprayed area produced 5,346 pounds.
Koshi (1957) studied the response of herbage production in East Texas by partial and complete removal of an oak overstory. Data indicated that a five-fold increase in grass production was maintained for a 3-year period by complete overstory removal.

We studied the effects of several herbicides on the production of grasses and forbs at four locations in Texas following weed and brush control, using low, moderate, and high rates of herbicides.

\section{Material and Methods}

\section{Field Sites}

Field plots were established near Victoria, Carlos, Llano, and Marble Falls, Texas. This provided an appreciable range in climate, edaphic conditions, and botanical composition of vegetation.

A dense stand of shrub-type live oak (Quercus virginiana Mill.) 3 to 12 feet tall was studied at Victoria, on the Gulf Coast Prairie. Herbaceous vegetation included little bluestem (Andropogon scoparius Michx.), brownseed paspalum (Paspalum plicatulum Michx.), Indiangrass (Sorghastrum nutans (L.) Nash), threeawn (Aristida spp.), lovegrass (Eragrostis spp.), knotroot bristlegrass (Setaria grisebachii Fourn.), bitter sneezeweed (Helenium amarum (Rafin.) H. Rock), and Lindheimer croton (Croton lindheimeri (Engelm. \& Gray) Wood). The average Katy gravelly sandy loam profile consisted of a light brownish-gray, gravelly, sandy loam surface layer about 20 inches thick having a pH of 5.5 and a gravel content of 10 to 30 percent. The subsoil was gray, sandy clay with yellowish brown and red mottles and centered around small iron concretions. It had a moderate to coarse blocky structure and a $\mathrm{pH}$ of 5.0 to 6.0 . The amount of sand increased with depth, and a few calcium carbonate concretions occurred at depths of 54 to 60 inches in many places.

Llano and Marble Falls, Texas, are located in the Central Basin.
Whitebrush (Aloysia lycioides Cham.) 4 to 7 feet tall predominated with scattered plants of honey mesquite, Texas persimmon (Diospyros texana Scheele), pricklypear (Opuntia spp.) and tasajillo (Opuntia leptocaulis DC.). Major grasses in the area were sideoats grama (Bouteloua curtipendula (Michx.) Torr.), curlymesquite (Hilaria belangeri (Steud.) Nash), vine mesquite (Panicum obtusum H.B.K.), and buffalograss (Buchloe dactyloides (Nutt.) Engelm.).

The granite soils near Marble Falls and Llano contained from 30 to $50 \%$ gravel. The surface soil was deep with 18 to 24 inches of a light brown gravelly, loamy sand. The subsoil was a red or yellow and gray clay. The surface soil absorbed water well, but the heavy subsoil took it slowly.

The predominant brush species at the Carlos site were yaupon (Ilex vomitoria Ait.), post oak (Quercus stellata Wangenh.), and blackjack oak (Quercus marilandica Muenchh.). The yaupon and oaks were 3 to 8 feet and 4 to 15 feet tall, respectively. Predominant herbaceous species were little bluestem, bristlegrass, Indiangrass, brownseed paspalum, Lindheimer croton, and bitter sneezeweed. The soil at the Carlos site was an Axtell fine sandy loam, shallow variant. The A horizon was a gray fine sandy loam to a depth of 5 to 10 inches. The dark, heavy clay of the $B$ horizon caused a perched water table in rainy season, but the $\mathrm{C}$ horizon gave excessive subdrainage. Consequently, the soil had characteristics of both a wet and dry soil.

\section{Brush Control}

We applied herbicides as sprays to plots in a randomized block design with two or three replications per treatment at Victoria, Llano and Carlos, Texas. Plots were either 20- or 22-ft wide and 100- or 200-ft long. We applied herbicides with a truck or tractor sprayer in 10 gallons spray per acre, except bromacil which was applied in 20 gallons per acre. 
Table 1. Rainfall data (inches) for years and locations where vegetation was sampled following brush control in Texas. ${ }^{1}$

\begin{tabular}{|c|c|c|c|c|c|c|c|c|c|}
\hline Location and year & March & April & May & June & July & Aug. & Sept. & Oct. & $\begin{array}{c}\text { Total } \\
\text { for year } \\
\text { (Jan. 1- } \\
\text { Dec. 30) }\end{array}$ \\
\hline $\begin{array}{l}\text { Victoria, } 1963 \\
\text { Departure from normal }\end{array}$ & $\begin{array}{r}0.25 \\
-2.07\end{array}$ & $\begin{array}{r}0.84 \\
-1.78\end{array}$ & $\begin{array}{r}1.58 \\
-2.54\end{array}$ & $\begin{array}{l}4.89 \\
1.89\end{array}$ & $\begin{array}{r}1.48 \\
-2.13\end{array}$ & $\begin{array}{r}3.02 \\
-0.11\end{array}$ & $\begin{array}{r}1.23 \\
-3.00\end{array}$ & $\begin{array}{r}1.25 \\
-2.23\end{array}$ & $\begin{array}{r}22.05 \\
-14.15\end{array}$ \\
\hline $\begin{array}{l}\text { Victoria, } 1964 \\
\text { Departure from normal }\end{array}$ & $\begin{array}{r}2.10 \\
-0.22\end{array}$ & $\begin{array}{r}0.50 \\
-2.12\end{array}$ & $\begin{array}{r}3.09 \\
-1.03\end{array}$ & $\begin{array}{l}3.77 \\
0.73\end{array}$ & $\begin{array}{r}1.81 \\
-1.80\end{array}$ & $\begin{array}{l}6.84 \\
3.71\end{array}$ & $\begin{array}{l}7.64 \\
3.41\end{array}$ & $\begin{array}{r}0.34 \\
-3.14\end{array}$ & $\begin{array}{l}33.22 \\
-2.88\end{array}$ \\
\hline $\begin{array}{l}\text { Victoria, } 1967 \\
\text { Departure from normal }\end{array}$ & $\begin{array}{r}0.49 \\
-1.83\end{array}$ & $\begin{array}{r}1.72 \\
-0.90\end{array}$ & $\begin{array}{r}2.38 \\
-1.74\end{array}$ & $\begin{array}{c}\mathrm{T} \\
-3.04\end{array}$ & $\begin{array}{r}1.26 \\
-2.35\end{array}$ & $\begin{array}{r}3.03 \\
-0.10\end{array}$ & 14.52 & 4.92 & $\begin{array}{l}33.90 \\
-2.30\end{array}$ \\
\hline $\begin{array}{l}\text { Llano, } 1967 \\
\text { Departure from normal }\end{array}$ & $\begin{array}{r}1.13 \\
-0.32\end{array}$ & $\begin{array}{r}2.40 \\
-0.55\end{array}$ & $\begin{array}{l}6.61 \\
2.62\end{array}$ & $\begin{array}{c}\mathrm{T} \\
-2.58\end{array}$ & $\begin{array}{r}0.72 \\
-1.30\end{array}$ & $\begin{array}{r}1.31 \\
-0.41\end{array}$ & $\begin{array}{l}4.40 \\
3.03\end{array}$ & $\begin{array}{l}0.96 \\
0.65\end{array}$ & $\begin{array}{l}25.52 \\
-3.07\end{array}$ \\
\hline Carlos, 1967 (College Station) & 1.78 & 3.78 & 6.78 & 0.25 & 4.58 & 1.35 & 4.69 & 3.68 & 32.49 \\
\hline Carlos, 1968 (College Station) & 1.94 & 6.28 & 6.90 & 12.63 & 6.10 & 0.18 & 4.38 & 2.48 & 61.04 \\
\hline $\begin{array}{l}\text { Victoria, } 1970 \\
\text { Departure from normal }\end{array}$ & $\begin{array}{l}4.44 \\
2.12\end{array}$ & $\begin{array}{r}2.38 \\
-0.24\end{array}$ & $\begin{array}{l}5.81 \\
4.11\end{array}$ & $\begin{array}{r}2.87 \\
-0.17\end{array}$ & $\begin{array}{r}3.51 \\
-0.10\end{array}$ & $\begin{array}{r}1.44 \\
-1.69\end{array}$ & $\begin{array}{l}7.41 \\
3.18\end{array}$ & $\begin{array}{r}2.63 \\
-0.85\end{array}$ & $\begin{array}{r}39.78 \\
3.58\end{array}$ \\
\hline Marble Falls, 1970 (Burnet) & 3.67 & 2.28 & 6.09 & 6.78 & 0.58 & 0.04 & 4.44 & 2.09 & 25.22 \\
\hline Carlos, 1970 (College Station) & 3.97 & 4.26 & 3.51 & 0.84 & 0.65 & 0.20 & 4.12 & 4.30 & 33.85 \\
\hline
\end{tabular}

${ }^{1}$ From "Climatological Data" U. S. Dep. of Commerce, National Climatic Center, Federal Bldg., Asheville, N.C. 28801.

Herbicides studied included the dimethylamine salt of 3,6-dichloro$o$-anisic acid (dicamba), 2-ethylhexyl ester formulations of 2,4-D and $2,4,5-\mathrm{T}$, the potassium salt of 4 amino-3,5,6-trichloropicolinic acid (picloram), 1,1'-dimethyl-4,4'-bipyridinium salts (paraquat), 5-bromo-3sec-butyl-6-methyluracil (bromacil), and 5-bromo-3-isopropyl-6-methyluracil (isocil). Additional formulations applied at Marble Falls, Texas, included the propylene glycol butyl ether esters of 2,4-D and 2,4,5-T, the isooctyl ester of picloram, the triethylamine salts of 2 , $4,5-\mathrm{T}$ plus picloram $(1: 1)$, the triisopropanolamine salt of 2,4-D plus picloram (1:2) and the dimethylamine salt of [(4-chloro-o-tolyl)oxy] acetic acid (MCPA).

Percentage of brush controlled was estimated at the time of forage harvest. Grasses and broadleaf plants were separated and ovendried after harvesting two, 2.8 by $10-\mathrm{ft}$ areas in each plot at the ground level. One experiment at Carlos involved broadcast applications of 2 percent picloram granules at 2 and $4 \mathrm{lb}$./acre to different plots ( 40 by $40 \mathrm{ft}$ ) each month for two years. One square meter of forage of the standing crop was harvested from the middle of each plot in October 1970.

\section{Pasture Weed Control}

We applied granules and sprays of 2-chloro-4-(ethylamino)-6-(isopropylamino)-s-triazine (atrazine), 2 chloro-4,6-bis(ethylamine)-s-triazine (simazine) and the potassium salt of picloram to triplicate, 10 by 30 $\mathrm{ft}$ plots. All herbicides were applied at 1/2, 1 and $2 \mathrm{lb}$./acre and were compared with equal rates of 2,4-D sprays for weed control in native pastures. Sprays were applied at 20 gallons/acre with a hand sprayer. Granules were broadcast by hand. Plots were usually clipped for forage yields at the end of each growing season in which the treatments were made, similar to that described in the previous section.

\section{Results and Discussion}

\section{Forage Production Following Brush Control}

Preliminary studies (data not shown) established in the fall (1963) and spring (1964) indicate a rapid release of native grasses where high rates of herbicides were used for control of live oak at Victoria, Texas. For example, 2,4,5-T sprayed in April 1964 at 8 and 12 lb./acre reduced the live oak canopy 55 and $68 \%$, respectively, 6 months after treatment and resulted in production of over $1600 \mathrm{lb}$./acre of oven- dry grass, compared to $100 \mathrm{lb}$./ acre of grasses in the control. Other treatments which produced increased grass production (1200 to $1600 \mathrm{lb}$./acre) about one year after treatment included summer applications of bromacil at $5 \mathrm{lb}$./acre, 2,4,5-T plus dicamba at $4+4$ lb./ acre, and fall treatments of picloram at 4 and $8 \mathrm{lb}$./acre, picloram plus 2,4-D at $0.8+3.2$ and $1.6+$ $6.4 \mathrm{lb}$./acre. Bromacil at $10 \mathrm{lb}$./ acre, and paraquat plus bromacil at $4+5 \mathrm{lb}$./acre applied in October, resulted in excellent live oak control, but retarded growth of grasses. Less than 500 lb./acre oven-dry grass occurred on these plots. Bromacil applied at $10 \mathrm{lb}$./acre in August apparently killed all vegetation. Below normal rainfall during 1963 and 1964 (Table 1) apparently prolonged the persistence of bromacil, and treated areas were void of vegetation at least one year. Grass production in all areas was less than normal because of limited rainfall.

Vegetation was harvested in October 1970 from plots treated in 1963 to 1965 which had the best live oak control (Table 2). Grasses and forbs arising, apparently from seed, were on plots where originally vegetation was killed by treatment with bromacil and isocil in August 
Table 2. Yields (lb./acre, oven-dry) of vegetation in October 1970 after treatment of live oak infested ranges near Victoria, Texas, at various times with various herbicides and herbicide rates (lb./acre).1.2

\begin{tabular}{|c|c|c|c|c|c|c|c|}
\hline \multirow[b]{2}{*}{$\begin{array}{l}\text { Date of } \\
\text { treatment }\end{array}$} & \multicolumn{2}{|l|}{ Treatment } & \multicolumn{5}{|c|}{ Yield } \\
\hline & Herbicide & Rate & Grasses & Forbs & $\begin{array}{l}\text { Live oak } \\
\text { regrowth }\end{array}$ & $\begin{array}{l}\text { Rubus } \\
\text { spp. }\end{array}$ & Total \\
\hline \multirow[t]{2}{*}{ August 1963} & Bromacil & 10 & $1850 \mathrm{abc}$ & $340 \mathrm{abc}$ & $0 \mathrm{a}$ & $55 \mathrm{ab}$ & $2245 \mathrm{ab}$ \\
\hline & Isocil & 10 & $2400 \mathrm{ab}$ & $270 \mathrm{abc}$ & $5 a$ & $25 \mathrm{~b}$ & $2700 \mathrm{a}$ \\
\hline \multirow[t]{2}{*}{ October 1963} & Bromacil & 10 & $1480 \mathrm{abc}$ & $320 \mathrm{abc}$ & $0 \mathrm{a}$ & $150 \mathrm{a}$ & $1950 \mathrm{ab}$ \\
\hline & Paraquat + Bromacil & $4+5$ & $1850 \mathrm{bc}$ & $480 \mathrm{ab}$ & $0 \mathbf{a}$ & $75 \mathrm{ab}$ & $1905 \mathrm{ab}$ \\
\hline \multirow[t]{2}{*}{ October 1964} & Picloram & 8 & $1680 \mathrm{abc}$ & $380 \mathrm{abc}$ & $0 \mathbf{a}$ & $95 \mathrm{ab}$ & $2155 \mathrm{ab}$ \\
\hline & Bromacil & 10 & $1570 \mathrm{abc}$ & $480 \mathrm{ab}$ & $20 \mathrm{a}$ & $130 \mathrm{a}$ & $2200 \mathrm{ab}$ \\
\hline \multirow[t]{2}{*}{ June 1965} & Picloram & 8 & $2400 \mathrm{ab}$ & $400 \mathrm{abc}$ & $100 \mathrm{~b}$ & $50 \mathrm{ab}$ & $2950 \mathrm{a}$ \\
\hline & Bromacil & 8 & $1400 \mathrm{bc}$ & $630 a$ & $20 a$ & $90 \mathrm{ab}$ & $2140 a b$ \\
\hline None-original stand & & & $0 d$ & $0 \mathrm{c}$ & $0 a$ & $0 \mathrm{~b}$ & $0 c$ \\
\hline Cleared and mowed 3 & - & - & $2530 \mathrm{a}$ & $130 \mathrm{bc}$ & $190 \mathrm{c}$ & $60 \mathrm{ab}$ & $2910 a$ \\
\hline Mowed-April 1970 & - & - & $20 \mathrm{~d}$ & $20 \mathrm{bc}$ & $1020 d$ & $10 \mathrm{~b}$ & $1070 \mathrm{bc}$ \\
\hline
\end{tabular}

1 Original live oak -5 to $6 \mathrm{ft}$ tall with stem diameters $1 / 2$ to 2 inches.

2 Plots grazed lightly since 1967 until April 1970.

3 Dozed July 1963; mowed July 1964, 1965, 1966 and April 1970.

1963. Grass production was lower where bromacil and paraquat plus bromacil were applied in October and bromacil applied in June, than the plots maintained by frequent mowing. However, grass yields were higher on all treated plots as compared to production from the original live oak stand or live oak mowed in April 1970. Forb production increased on treated areas. Rubus spp. appeared to encroach most on areas treated with bromacil. All herbicide plots were mowed and cleared of debris in April 1970 to enable mechanical harvesting of the vegetation. The mowing treatment, early light grazing until April 1970, and below normal rainfall (Table 1) during the growing season probably reduced the grass production potential.

Studies established in April 1969 through March 1970 indicated that substantial increases in grass production are possible following brush control with pelleted picloram (Table 3). Areas treated in May, June, September, October and February produced significantly more grass than the untreated areas. The winter treatments, such as those in February, are of special interest since they resulted in excellent brush control and grass pro- duction. Mid-winter treatments of granular herbicides would also minimize any hazard to crops from drift, volatilization or runoff water since sensitive crops are not grown during winter in this area. August treatments, applied when hot and

dry, resulted in poorer brush control and lower grass yields at $2 \mathrm{lb}$./ acre, than treatments applied during other months.

Grass release as a result of controlling yaupon and associated woody species near Carlos, Texas,

Table 3. Oven-dry yields (lb./acre) of vegetation in October 1970 and control 1 (\%) of yaupon after treatment of yaupon infested ranges near Carlos, Texas, with picloram granules (lb./acre) at various dates. ${ }^{2}$

\begin{tabular}{|c|c|c|c|c|c|c|}
\hline $\begin{array}{c}\text { Pic- } \\
\text { loram } \\
\text { gran- } \\
\text { ules } \\
\text { (lb./acre) }\end{array}$ & $\begin{array}{c}\text { Date of } \\
\text { application }\end{array}$ & $\begin{array}{l}\text { Yaupon } \\
\text { control }\end{array}$ & $\begin{array}{l}\text { Grass } \\
\text { yield }\end{array}$ & $\begin{array}{c}\text { Date of } \\
\text { application }\end{array}$ & $\begin{array}{l}\text { Yaupon } \\
\text { control }\end{array}$ & $\begin{array}{l}\text { Grass } \\
\text { yield }\end{array}$ \\
\hline 2 & April 1969 & $90 \mathrm{ab}$ & $1857 \mathrm{abc}$ & April 1970 & $95 \mathrm{ab}$ & $2857 a$ \\
\hline 4 & & $97 a$ & $2284 \mathrm{abc}$ & & $98 a$ & $2149 a$ \\
\hline 2 & May 1969 & $75 \mathrm{~cd}$ & $1513 \mathrm{abc}$ & May 1970 & $100 \mathrm{a}$ & $1114 \mathrm{~b}$ \\
\hline 4 & & $99 \mathrm{a}$ & $2840 \mathrm{ab}$ & & $100 a$ & $917 \mathrm{bc}$ \\
\hline 2 & June 1969 & $95 \mathrm{ab}$ & $2700 \mathrm{ab}$ & June 1970 & $78 c$ & $843 b c$ \\
\hline 4 & & $93 a b$ & $1422 \mathrm{abc}$ & & $100 a$ & $199 c$ \\
\hline 2 & August 1969 & $65 d$ & $134 \mathrm{Ibc}$ & July 1970 & $68 d$ & $695 \mathrm{bc}$ \\
\hline 4 & & $95 \mathrm{ab}$ & $2073 \mathrm{abc}$ & & $90 \mathrm{ab}$ & $423 \mathrm{bc}$ \\
\hline 2 & September 1969 & $95 \mathrm{ab}$ & $3055 \mathrm{ab}$ & August 1970 & $40 \mathrm{f}$ & $122 \mathrm{c}$ \\
\hline 4 & & $100 \mathrm{a}$ & $2719 \mathrm{ab}$ & & $50 \mathrm{e}$ & $692 b c$ \\
\hline 2 & October 1969 & $95 \mathrm{ab}$ & $2491 \mathrm{abc}$ & September 1970 & $30 \mathrm{~g}$ & $125 \mathrm{c}$ \\
\hline 4 & & $95 a b$ & $2788 \mathrm{ab}$ & & $50 \mathrm{e}$ & $133 \mathrm{c}$ \\
\hline 2 & February 1970 & $99 a$ & $2669 \mathrm{ab}$ & October 1970 & $0 \mathrm{~h}$ & $178 \mathrm{c}$ \\
\hline 4 & & $98 \mathrm{a}$ & $3190 a$ & & $0 \mathrm{~h}$ & $263 c$ \\
\hline \multicolumn{2}{|l|}{ Control } & $0 e$ & $844 c$ & & $0 \mathrm{~h}$ & $406 \mathrm{bc}$ \\
\hline
\end{tabular}

${ }^{1}$ Estimates of canopy reduction of yaupon (Ilex vomitoria Ait.) at time of forage harvest.

${ }^{2}$ Values within a column followed by the same letter are not significantly different at the $5 \%$ level. 
Table 4. Vegetation production (lb./acre, oven-dry) in October 1970 after treatment of yaupon infested ranges near Carlos, Texas, at various dates with picloram or picloram plus paraquat mixtures. ${ }^{1}$

\begin{tabular}{lclcc}
\hline \hline \multirow{2}{*}{ Treatment } & \multirow{2}{*}{$\begin{array}{c}\text { Rate } \\
\text { (lb./acre) }\end{array}$} & $\begin{array}{c}\text { Date of } \\
\text { application }\end{array}$ & Grasses & Forbs \\
\cline { 4 - 5 } Picloram & 8 & May 1964 & $908 \mathrm{a}$ & $99 \mathrm{ab}$ \\
Picloram + paraquat & $4+4$ & May 1964 & $982 \mathrm{a}$ & $94 \mathrm{ab}$ \\
Picloram & 8 & June 1964 & $757 \mathrm{a}$ & $39 \mathrm{~b}$ \\
Picloram + paraquat & $4+4$ & Junc 1964 & $962 \mathrm{a}$ & $65 \mathrm{ab}$ \\
Picloram & 4 & June 1964 & $749 \mathrm{ab}$ & $128 \mathrm{ab}$ \\
Picloram & 8 & October 1964 & $1061 \mathrm{a}$ & $74 \mathrm{ab}$ \\
Picloram & 8 & May 1965 & $751 \mathrm{a}$ & $71 \mathrm{ab}$ \\
Picloram + paraquat & $4+4$ & May 1965 & $924 \mathrm{a}$ & $103 \mathrm{ab}$ \\
Picloram + paraquat & $4+2$ & May 1965 & $736 \mathrm{ab}$ & $172 \mathrm{a}$ \\
\multicolumn{1}{c}{ Control } & & & $406 \mathrm{c}$ & $0 \mathrm{~b}$ \\
\hline
\end{tabular}

${ }^{1}$ All brush killed including yaupon (Ilex vomitoria Ait.), winged elm (Ulmus alata Michx.), post oak (Quercus stellata Wangenh.) and blackjack oak (Quercus marilandica Muenchh.).

${ }^{2}$ Values within a column followed by the same letter are not significantly different at the 5\% lcvel. Close mowing of all plots in April and grazing in May of 1970 reduced the amount of vegetation present at harvest time.
Forage Production Following Weed Control

Plots were established in 1967 to study the relative tolerance of grasses when treated with promising herbicides for control of herbaceous weeds in pastures. Data for herbicides applied at $1 / 2$ and $1 \mathrm{lb}$./acre are not shown since there were usually no significant differences among treated and untreated plots (Table 6). Forb populations were low as indicated in the untreated control plots at all locations in 1967 and 1968. Low rainfall after treatment, especially at Llano and Victoria, tended to mask weed control effects due to poor growing conditions. Grass production was lowest at Llano and highest at Carlos.

No significant differences occurred in grass production betwecn herbicide-treated and untreated areas 6 months after application at

Table 5. Vegetation production (lb./acre, oven-dry) in October 1970 and whitebrush control (\%) after treatment of rangeland near Marble Falls, Texas, with various herbicides in May and September 1966 and May 1969.1

\begin{tabular}{|c|c|c|c|c|c|c|}
\hline \multirow{2}{*}{$\begin{array}{c}\text { Date of } \\
\text { application }\end{array}$} & \multirow[b]{2}{*}{ Treatment } & \multirow[b]{2}{*}{ Rate (Ib./acre) } & \multicolumn{2}{|c|}{ Whitebrush control ${ }^{2}$} & \multicolumn{2}{|c|}{ Oven-dry yield" } \\
\hline & & & Defoliation & Dead & Grasses & Forbs \\
\hline \multirow[t]{12}{*}{ May 1969} & MCPA & 1 & $70 \mathrm{~d}$ & $0 \mathrm{~d}$ & $1133 \mathrm{~cd}$ & $30 \mathrm{lbd}$ \\
\hline & Picloram & 1 & $95 \mathrm{ab}$ & $55 \mathrm{ab}$ & $2435 a$ & $0 \mathrm{~d}$ \\
\hline & Picloram & 0.5 & $90 \mathrm{ab}$ & $30 \mathrm{bcd}$ & $2322 \mathrm{a}$ & $8 \mathrm{~d}$ \\
\hline & $\begin{array}{l}\text { Picloram }+2,4,5-\mathrm{T} \\
\quad \text { (amine salts) }\end{array}$ & $0.5+0.5$ & $92 \mathrm{ab}$ & $40 \mathrm{bcd}$ & 1940ab & $8 d$ \\
\hline & $\begin{array}{l}\text { Picloram }+2,4,5-\mathrm{T} \\
\quad \text { (ester) }\end{array}$ & $0.5+0.5$ & $92 a b$ & 35bcd & $2240 a$ & $8 \mathrm{~d}$ \\
\hline & $2,4,5-\mathrm{T}$ & 1 & $29 \mathrm{e}$ & $0 d$ & $939 \mathrm{~d}$ & $450 \mathrm{~b}$ \\
\hline & Picloram + 2,4-D & $0.33+0.67$ & $86 \mathrm{bc}$ & $15 \mathrm{~cd}$ & $2403 a$ & $12 \mathrm{~d}$ \\
\hline & $2,4-D$ & 1 & $79 \mathrm{~cd}$ & $15 \mathrm{~cd}$ & $1696 a b c d$ & $31 d$ \\
\hline & Picloram + dicamba & $0.5+0.5$ & $94 \mathrm{ab}$ & $45 \mathrm{bc}$ & $1802 \mathrm{abc}$ & $12 \mathrm{~d}$ \\
\hline & Dicamba & 1 & $13 \mathrm{f}$ & $0 \mathrm{~d}$ & $1396 \mathrm{bcd}$ & $70 \mathrm{~d}$ \\
\hline & Picloram ${ }^{3}$ & 1 & $94 a b$ & $55 \mathrm{ab}$ & $2303 a$ & $0 \mathrm{~d}$ \\
\hline & Control & - & $10 \mathrm{f}$ & $0 \mathrm{~d}$ & $851 d$ & $821 a$ \\
\hline \multirow[t]{2}{*}{ May 1966} & Picloram & 2 & $98 \mathrm{a}$ & $85 a$ & 1934ab & $98 \mathrm{~cd}$ \\
\hline & Picloram & 3 & $98 \mathrm{a}$ & $85 a$ & $2140 \mathrm{ab}$ & $4 d$ \\
\hline \multirow[t]{5}{*}{ September 1966} & Picloram & 1 & $93 \mathrm{ab}$ & $60 \mathrm{ab}$ & $1371 \mathrm{bcd}$ & $203 \mathrm{~cd}$ \\
\hline & Picloram & 2 & $99 \mathrm{a}$ & $95 a$ & $2209 a$ & $0 \mathrm{~d}$ \\
\hline & Picloram & 3 & $99 a$ & $90 a$ & 2153ab & $4 d$ \\
\hline & MCPA & 2 & $18 \mathrm{f}$ & $0 \mathrm{~d}$ & $951 d$ & $493 \mathrm{~b}$ \\
\hline & Control & - & lof & Od & $976 \mathrm{~d}$ & $325 \mathrm{bc}$ \\
\hline
\end{tabular}

1 Brush is predominately whitebrush (Aloysia lycioides Cham.) with scattered plants of tasajillo (Opuntia leptocaulis DC.) and Texas persimmon (Diospyros texana Scheele).

${ }^{2}$ Values followed by the same letter do not differ at the .05 level of significance.

${ }^{3}$ Isooctyl ester. 
Table 6. Oven-dry production (lb./acre) of herbaceous vegetation following weed control in pastures at three locations in Texas. 1

\begin{tabular}{|c|c|c|c|c|c|c|}
\hline \multirow[b]{2}{*}{ Herbicide } & \multicolumn{2}{|c|}{ Llano $^{2}$} & \multicolumn{2}{|c|}{ Victoria $^{2}$} & \multicolumn{2}{|c|}{ Carlos $^{2}$} \\
\hline & Grass & Forbs & Grass & Forbs & Grass & Forbs \\
\hline Atrazine spray & $1339 a$ & 2 & 2311 & 3 & 3814 & 7 \\
\hline Atrazine granules & $620 \mathrm{ab}$ & 6 & 2083 & 79 & 4456 & 19 \\
\hline Simazine spray & $1193 \mathrm{ab}$ & 3 & 1864 & 30 & 4454 & 1 \\
\hline Simazine granules & $1243 \mathrm{ab}$ & 172 & 2129 & 115 & 4082 & 62 \\
\hline Picloram spray & $1058 \mathrm{ab}$ & 10 & 1818 & 17 & 3888 & 0 \\
\hline Picloram granules & $397 \mathrm{~b}$ & 0 & 2519 & 5 & 4321 & 0 \\
\hline 2,4-D spray & $519 a b$ & 38 & 1693 & 96 & 4481 & 6 \\
\hline Control & $1086 \mathrm{ab}$ & 228 & 1649 & 165 & 3267 & 325 \\
\hline
\end{tabular}

${ }^{1}$ Treated with $2 \mathrm{lb}$./acre of all herbicides, March 16, 17 and 20, 1967; harvested September 13, October 4 and September 18, 1967, for Carlos, Victoria and Llano, Texas, respectively.

${ }^{2}$ Values within column one followed by the same letter are not significantly different at the $5 \%$ level; values in all other columns are not significantly different.

Llano, Texas. However, picloram granules at $2 \mathrm{lb}$./acre tended to reduce grass and forb production. Highcst grass yields at Victoria were produced in plots receiving picloram granules at $2 \mathrm{lb}$./acre. Trends were apparent among treatments, but no significant increases occurred in grass and forb production due to weed control. At Carlos, Texas, no differences occurred among treatments but grass production tended to increase as application rate was increased. Picloram sprays and granules at $2 \mathrm{lb}$./acre eliminated all forbs.

Table 7. Oven-dry production (lb./acre) of herbaccous vegetation following herbicide applications at three dates on pastures at Carlos, Texas. ${ }^{1}$

\begin{tabular}{|c|c|c|c|c|c|c|}
\hline \multirow[b]{2}{*}{ Herbicide } & \multicolumn{2}{|c|}{ Spring $1968^{2}$} & \multicolumn{2}{|c|}{ Fall $1968^{2}$} & \multicolumn{2}{|c|}{ Spring $1967^{2}$} \\
\hline & Grass & Forbs & Grass & Forbs & Grass & Forbs \\
\hline Atrazine spray & 3328 & 54 & 3665 & 345 & 3758 & 163 \\
\hline Atrazine granules & 4107 & 0 & 3578 & 145 & 2596 & 109 \\
\hline Simazine spray & 3287 & 18 & 3746 & 182 & 4030 & 36 \\
\hline Simazine granules & 2997 & 36 & 3972 & 127 & 2805 & 18 \\
\hline Picloram spray & 3165 & 0 & 3723 & 454 & 4426 & 381 \\
\hline Picloram granules & 2942 & 0 & 3195 & 435 & 3142 & 254 \\
\hline 2,4-D spray & 3322 & 0 & 3107 & 454 & 2796 & 363 \\
\hline Control & 3078 & 170 & 2977 & 299 & 3009 & 423 \\
\hline
\end{tabular}

1 Treated with $2 \mathrm{lb}$./acre of all herbicides, March 16, 1967; October 1967 and April 6, 1968 and harvested November 5, 6 and July 1968.

2 Values in all columns are not significantly different at the $5 \%$ lcvcl.

\section{Literature Cited}

ARnold, W. R., AND P. W. Santlemann. 1966. The response of native grasses and forbs to picloram. Weeds 14: $74-76$.

BARRons, K. C. 1969. Some ecological benefits of woody plant control with herbicides. Science 165:465-468.

Bentley, J. R. 1967. Conversion of chaparral areas to grassland: techniques used in California. U.S. Dep. Agr., Agr. Handbook No. 328.35 p.

Bovey, R. W., and C. J. ScIFres. 1971. Residual characteristics of picloram in the grassland ecosystems. Texas Agr. Exp. Sta. Bull. 1111. 24 p.

EHRENREICH, J. H., AND R. F. ButTeRY. 1960. Increasing forage on Ozark wooded range. U.S. Dep. Agr. Forest Serv. Tech. Paper 177. 10 p.

Fisher, C. E., C. H. Meadors, R. Behrens, E. D. Robison, P. T. Marion, AND H. L. Morton. 1959. Control of mesquite on grazing lands. Texas Agr. Exp. Sta. Bull. 935. 24 p.

Hoffman, G. O. 1966. Chemical control of Macartney rose and unpalatable weeds pays. Down-to-Earth 22(3):8-11.

KLingman, D. L., AND M. K. MCCarty. 1958. Interrelations of methods of weed control and pasture management at Lincoln, Nebraska, 1949-55. U. S. Dep. Agr. and Nebraska Agr. Exp. Sta. Tech. Bull. No. 1180. 49 p.

KosHI, P. 'I. 1957. An evaluation of forage production, vegetational composition, tree growth and physical characteristics of soils under varying densities of oak woodland overstory. Ph.D. Diss., Texas A\&M Univ. 116 p.

Meyer, R. E., T. E. Riley, H. L. MoRTON, AND M. G. Merkle. 1969. Control of whitebrush and associated species with herbicides in Texas. Texas Agr. Exp. Sta., Misc. Publ. 930. $18 \mathrm{p}$.

Robison, E. D. AND C. E. Fisher. 1968. Chemical control on sand shinnery oak and related forage production. Brush Research in Texas 1968. Texas Agr. Exp. Sta. Prog. Rept. 2583. $79 \mathrm{p}$.
Longmont Seed Co. We Buy \& Sell Western Range Grass \& Legume Seeds CONFRONT US with your RANGE PROBLEMS: phone: $303+776-1320$ LONGMONT, COLORADO 80501 